\title{
Mutant Wars2 Gene in Spontaneously Hypertensive Rats Impairs Brown Adipose Tissue Function and Predisposes to Visceral Obesity
}

\author{
M. PRAVENEC ${ }^{1}$, V. ZÍDEK ${ }^{1}$, V. LANDA ${ }^{1}$, P. MLEJNEK ${ }^{1}, J_{\text {. ŚILHAVÝ }}{ }^{1}$, M. ŠIMÁKOVÁ ${ }^{1}$, \\ J. TRNOVSKÁ ${ }^{2}$, V. ŠKOP ${ }^{2}$, I. MARKOVÁ ${ }^{2}$, H. MALÍNSKÁ ${ }^{2}$, M. HÜTTL ${ }^{2}$, L. KAZDOVÁ ${ }^{2}$, \\ K. BARDOVÁ ${ }^{1}$, K. TAUCHMANNOVÁ ${ }^{1}$, M. VRBACKÝ ${ }^{1}$, H. NƯSKOVÁ ${ }^{1}$, T. MRÁČEK ${ }^{1}$, \\ J. KOPECKÝ ${ }^{1}$, J. HOUŠTĚK ${ }^{1}$
}

${ }^{1}$ Institute of Physiology of the Czech Academy of Sciences, Prague, Czech Republic, ${ }^{2}$ Institute for Clinical and Experimental Medicine, Prague, Czech Republic

Received November 17, 2017

Accepted November 30, 2017

\section{Summary}

Brown adipose tissue (BAT) plays an important role in lipid and glucose metabolism in rodents and possibly also in humans. Identification of genes responsible for BAT function would shed light on underlying pathophysiological mechanisms of metabolic disturbances. Recent linkage analysis in the BXH/HXB recombinant inbred (RI) strains, derived from Brown Norway (BN) and spontaneously hypertensive rats (SHR), identified two closely linked quantitative trait loci (QTL) associated with glucose oxidation and glucose incorporation into BAT lipids in the vicinity of Wars2 (tryptophanyl tRNA synthetase 2 (mitochondrial)) gene on chromosome 2. The SHR harbors L53F WARS2 protein variant that was associated with reduced angiogenesis and Wars2 thus represents a prominent positional candidate gene. In the current study, we validated this candidate as a quantitative trait gene (QTG) using transgenic rescue experiment. SHR-Wars2 transgenic rats with wild type Wars2 gene when compared to SHR, showed more efficient mitochondrial proteosynthesis and increased mitochondrial respiration, which was associated with increased glucose oxidation and incorporation into BAT lipids, and with reduced weight of visceral fat. Correlation analyses in RI strains showed that increased activity of BAT was associated with amelioration of insulin resistance in muscle and white adipose tissue. In summary, these results demonstrate important role of Wars2 gene in regulating BAT function and consequently lipid and glucose metabolism.

\section{Key words}

Brown adipose tissue - Spontaneously hypertensive rat • Quantitative trait loci $\bullet$ Transgenic $\bullet$ Wars2 gene $\bullet$ Mitochondrial proteosynthesis

\section{Corresponding author}

M. Pravenec, Institute of Physiology of the Czech Academy of Sciences, Vídeňská 1083, 14220 Prague, Czech Republic. Fax: (420)241062488. E-mail: pravenec@biomed.cas.cz

\section{Introduction}

Metabolic syndrome is characterized by clustering of several risk factors including insulin resistance in skeletal muscle and adipose tissue, dyslipidemia and hypertension. Growing evidence indicates that brown adipose tissue (BAT) plays an important role in the pathogenesis of metabolic disturbances both in rodent models and in humans (Bartelt et al. 2011, Vijgen et al. 2011, Virtanen 2016). Identification of genes that regulate BAT function would shed light on underlying pathophysiological mechanisms of the metabolic syndrome. Recently, we performed linkage analyses of physiological phenotypes in BAT in $\mathrm{BXH} / \mathrm{HXB}$ recombinant inbred (RI) strains derived from SHR (spontaneously hypertensive rat) and BN (Brown Norway) progenitors. These linkage studies identified two closely linked quantitative trait loci (QTL) on chromosome 2 associated with glucose oxidation (the peak of QTL linkage at position $181 \mathrm{Mb}$ ) and glucose incorporation into BAT lipids (the peak of QTL linkage at position $200 \mathrm{Mb}$ ) in the vicinity of Wars2 (tryptophanyl tRNA synthetase 2 (mitochondrial)) gene (at position $201 \mathrm{Mb}$ ) (Pravenec et al. 2017). The SHR harbors mutant Wars2 allele, which codes for an L53F 
WARS2 protein variant within the ATP-binding motif and has been identified as a genetic determinant that predisposes the SHR to reduced angiogenesis in the heart and possibly in other tissues (Wang et al. 2016). The Wars 2 thus represents a prominent positional candidate gene for transgenic rescue experiments to identify QTL associated with BAT function at the molecular level. In the current study, we tried to identify the Wars 2 as a quantitative trait gene and to search for pathophysiological mechanisms underlying the associated phenotypes. Correlation analysis in RI strains was used to evaluate the association of BAT activity with insulin resistance in skeletal muscle and white adipose tissue.

\section{Materials and Methods}

\section{Animals}

The SHR/OlaIpcv strain (referred to as the SHR), SHR.BN-D2Rat171/D2Arb24 congenic strain with wild type Wars2 (referred to as SHR-2) (Pravenec et al. 2001) and the new SHR transgenic strain expressing wild type Wars 2 gene were housed in a facility with constant temperature $23{ }^{\circ} \mathrm{C}$ and $12 \mathrm{~h}$ light/dark cycle and allowed free access to standard laboratory chow and water. Transgenic SHR/Ola-Tg(EFla-Wars2) (referred to as the transgenic SHR-Wars2) strain was derived by microinjecting fertilized eggs with a mix of the Sleeping Beauty construct containing $\mathrm{BN}$ Wars 2 cDNA under control of the universal EF-1 $\alpha$ promoter and mRNA of the SB100X transposase (Ivics et al. 2014). Transgenic rats were detected using PCR with the following primers: Wars2-F 5'-TGT GCT ACA AGT CCA CAC AC-3' and Wars2-R 5'-GCA GAA GGG TCA CGA AGA GA-3'. Biochemical and metabolic phenotypes in both strains were assessed in 3-month-old non-fasted male rats $(n=8$ per strain). All experiments were performed in agreement with the Animal Protection Law of the Czech Republic and were approved by the Ethics Committee of the Institute of Physiology of the Czech Academy of Sciences, Prague.

Glucose utilization in BAT for oxidation and incorporation into lipids

Following decapitation in the non-fasted state, interscapular BAT was dissected and incubated for $2 \mathrm{~h}$ in Krebs-Ringer bicarbonate buffer with $5 \mathrm{mmol} / \mathrm{l}$ glucose, $0.1 \mu \mathrm{Ci}\left[\mathrm{U}_{-}{ }^{14} \mathrm{C}\right.$ ] glucose $/ \mathrm{ml}$ and $2 \%$ bovine serum albumin, gaseous phase $95 \% \mathrm{O}_{2}$ and $5 \% \mathrm{CO}_{2}$. Glucose oxidation was determined in BAT by measuring the incorporation of $\left[\mathrm{U}_{-}{ }^{14} \mathrm{C}\right]$ glucose into $\mathrm{CO}_{2}$. For measurement of incorporation of radiolabeled glucose into lipids, at the end of incubation, BAT was removed from media, rinsed in saline, and transferred into chloroform:methanol $(2: 1)$ where lipids were extracted and radioactivity measured.

\section{Gene expression determined by real-time PCR}

Total RNA was extracted from the BAT using Trizol reagent (Invitrogen, Waltham, USA) and cDNA was prepared and analyzed by real-time PCR testing using QuantiTect SYBR Green reagents (Qiagen, Inc., Venlo, Netherlands) on an Opticon continuous fluorescence detector (MJ Research, Waltham, USA). Gene expression levels were normalized relative to the expression of the peptidylprolyl isomerase A (Ppia) (cyclophilin) gene, which served as the internal control. The results were determined in triplicates. The following primers were used: Wars2-F 5'-GTG CTA CAA GTC CAC ACA CG-3'; Wars2-R 5'-GCA GAA GGG TCA CGA AGA GA-3'; Ppia-F 5'-AGC ATA CAG GTC CTG GCA T-3'; Ppia-R 5'-TCA CCT TCC CAA AGA CCA C-3'.

Tissue homogenates, isolated mitochondria and culture of rat skin fibroblasts

Preparation of tissue homogenates and isolation of heart mitochondria were carried as previously described (Pecinová et al. 2011), proteins were determined by the Bradford method (1976), using BSA as standard. Primary rat skin fibroblasts were prepared from 3 weeks old SHR and SHR-2 congenic animals according to Seluanov et al. (2010). Established cultures of skin fibroblasts were then maintained and subcultured at $37^{\circ} \mathrm{C}$ and $5 \% \mathrm{CO}_{2}$ in air in DMEM medium (Life Technologies, Waltham, USA) that was supplemented with $10 \%$ fetal calf serum (Sigma, St. Louis, USA) and penicillin/streptomycin solution (Life technologies).

\section{Western blotting}

Samples of fibroblasts or tissue homogenates were denatured at $56{ }^{\circ} \mathrm{C}$ for $15 \mathrm{~min}$ in a sample lysis buffer $(2 \%(\mathrm{v} / \mathrm{v})$ 2-mercaptoethanol, $4 \%(\mathrm{w} / \mathrm{v}) \mathrm{SDS}$, $50 \mathrm{mM}$ Tris-HCl, $\mathrm{pH} 7.0,10 \%$ (v/v) glycerol, $0.017 \%$ (w/v) Coomassie Brilliant Blue R-250) and Tricine SDS-PAGE was performed on $10 \%(\mathrm{w} / \mathrm{v})$ polyacrylamide slab gels. The gels were blotted onto a PVDF membrane (Immobilon-P, Merck Millipore) by semidry electrotransfer at $0.8 \mathrm{~mA} / \mathrm{cm}^{2}$ for $1 \mathrm{~h}$. Membranes were 
blocked in $5 \%$ non-fat dried milk dissolved in Tris-buffered saline (TBS; $150 \mathrm{mM} \mathrm{NaCl,} 10 \mathrm{mM}$ Tris- $\mathrm{HCl}, \mathrm{pH} 7.5)$ for $1 \mathrm{~h}$ at room temperature. Specific primary antibodies were used to assess the content of respiratory chain enzymes (SDHA, a subunit of complex II - ab14715; COX1, an mtDNA-encoded subunit of complex IV - ab14705; $F_{1}-\alpha$, a subunit of complex V - ab110273, all from Abcam, Cambridge, UK), mitochondrial content (porin - a kind gift from Professor de Pinto) and WARS2 protein (SC-22852, from Santa Cruz Biotechnology, Dallas, USA). For quantitative detection, the corresponding infra-red fluorescent secondary antibodies (Alexa Fluor 680, Life Technologies; IRDye 800, Rockland Immunochemicals, Limerick, USA) diluted in TBS supplemented with $0.1 \%$ (v/v) Tween-20 were used. The fluorescence was detected using ODYSSEY infra-red imaging system (LI-COR Biosciences, Lincoln, USA) and the signal was quantified using Aida 3.21 Image Analyzer software.

Metabolic pulse-chase labelling of mtDNA encoded proteins in SHR-2 congenic rats

The incorporation of ${ }^{35} \mathrm{~S}-\mathrm{Met}$ and ${ }^{35} \mathrm{~S}$-Cys into mtDNA-encoded proteins was investigated in the presence of emetine, an inhibitor of translation of nuclear-encoded proteins on cytosolic ribosomes. Cells were washed three times with PBS. 15-min incubation in DMEM medium without Met and Cys was followed by addition of emetine $(100 \mu \mathrm{g} / \mathrm{ml})$. After $15 \mathrm{~min}$, the medium was exchanged for DMEM medium supplemented with emetine and ${ }^{35}$ S-Protein Labelling Mix $\left({ }^{35} \mathrm{~S}-\right.$ Met+Cys, Perkin Elmer NEG072; $\left.200 \mu \mathrm{Ci} / \mathrm{ml}\right)$. Cells were incubated for $3 \mathrm{~h}$ at $37^{\circ} \mathrm{C}$, then $250 \mu \mathrm{M}$ cold Met and Cys was added. After $15 \mathrm{~min}$ at $37^{\circ} \mathrm{C}$, cells were washed twice with $\mathrm{PBS}+250 \mu \mathrm{M}$ cold Met and Cys and harvested by trypsin digestion (washed twice with PBS supplemented with a protease inhibitor cocktail - Sigma P8340). Samples for SDS-PAGE were prepared as described above, resolved on $10 \%$ gels and transferred to a PVDF membrane. The signal of incorporated radioactive Met and Cys was detected using Pharos FX ${ }^{\mathrm{TM}}$ Plus Molecular Imager (Bio-Rad Laboratories, Hercules, USA) and quantified using Aida 3.21 Image Analyzer software. Afterwards, the membrane was probed with specific antibodies (see Western blotting for details) and radioactive signals of mitochondrial proteins were normalized to the protein content of porin, a mitochondrial marker, as determined on Western blots.

\section{Respiration measurements}

Oxygen consumption was measured at $30^{\circ} \mathrm{C}$ as described before (Pecina et al. 2003) using Oxygraph-2k (Oroboros, Innsbruck, Austria). The isolated mitochondria $(0.05-0.1 \mathrm{mg} / \mathrm{ml})$ were suspended in $2 \mathrm{ml}$ of $\mathrm{KCl}$ medium $(80 \mathrm{mM} \mathrm{KCl}, 10 \mathrm{mM}$ Tris- $\mathrm{HCl}$, $3 \mathrm{mM} \mathrm{MgCl}_{2}, 1 \mathrm{mM}$ EDTA, $5 \mathrm{mM} \mathrm{K}-\mathrm{Pi}, 0.5 \mathrm{mg} / \mathrm{ml}$ $\mathrm{BSA}, \mathrm{pH}$ 7.4). For measurements, $10 \mathrm{mM}$ glutamate, $2.5 \mathrm{mM}$ malate, $10 \mathrm{mM}$ succinate and $1.5 \mathrm{mM}$ ADP were used. The oxygen consumption was expressed in pmol oxygen/s/mg protein, respiratory control index (RCI) was calculated as a ratio between ADP-stimulated respiration and respiration without ADP for the substrate used.

\section{Measurement of capillary number}

Tissue samples of BAT were fixed in $10 \%$ neutral buffered formalin (Sigma-Aldrich). $5 \mu \mathrm{m}$ thick sections were stained by isolectin IB4 (Isolectin GS-IB4 Alexa Fluor 568 conjugate, ThermoFisher Scientific) and by anti-perilipin A antibody (Abcam) followed by incubation with Alexa Fluor 633 anti-goat IgG secondary antibody (ThermoFisher Scientific) and DAPI, or by anti-sodium potassium ATPase antibody (Abcam) followed by incubation with ABC kit (Vector Laboratories, Burlingame, USA) and DAB (Sigma-Aldrich). For each treatment, a positive control with a known positivity for specific antibody and a negative control with omitted primary antibody were included. Digital images were captured using an Olympus AX70 light microscope and a DP 70 camera (Olympus, Japan) or Leica SP8 AOBS WLL MP confocal microscope. Vascularization was assessed by semi-automatic detection of isolectin-positive capillaries in 10 high-power fields related to number of adipocytes detected by autofluorescence.

\section{Statistical analysis}

The data are expressed as means \pm SEM. Individual groups were compared by Student t-test. Normality of distribution was tested by Shapiro-Wilk method. Statistical significance was defined as $\mathrm{P}<0.05$. Statistical analysis of gene expression data was performed using the REST XL program, which tests for significance using a randomization procedure (Pfaffl et al. 2002). Correlation analysis of glucose oxidation and incorporation into BAT lipids (Pravenec et al. 2017) with parameters of glucose and lipid metabolism in the BXH/HXB RI strains were performed using GeneNetwork database and online software (www.genenetwork.org) (Mulligan et al. 2017). 


\section{Results}

\section{In vivo functional studies}

To identify the two closely linked QTL on chromosome 2 at the molecular level as the Wars 2 gene variant, we measured glucose oxidation and incorporation into BAT lipids in new SHR-Wars2 transgenic rats. SHR-Wars 2 transgenic rats exhibited significantly higher expression of the wild type mRNA and WARS2 protein (Figs 1A and 1B) and increased glucose oxidation and incorporation into BAT lipids when compared to SHR rats (Fig. 1C). Increased glucose oxidation and incorporation into BAT lipids in SHR-Wars 2 transgenic rats versus SHR was associated with lower body weight (243 \pm 3 versus $282 \pm 2 \mathrm{~g}, \quad \mathrm{P}=0.000006)$ to which contributes reduced adiposity as suggested by decreased relative weight of epididymal fat in transgenic rats $(0.630 \pm 0.024$ versus $0.813 \pm 0.028 \mathrm{~g} / 100 \mathrm{~g}$ body weight, $\mathrm{P}=0.0006)$. Together, these findings provide the evidence that the mutant Wars2 is a quantitative trait gene (QTG) responsible for reduced glucose oxidation and glucose incorporation into BAT lipids in the SHR.

Effects of the mutant Wars2 gene on synthesis of mtDNA encoded proteins, respiration and enzyme activities

Mitochondrial proteosynthesis was measured in primary fibroblast culture from SHR strain and in SHR-2 congenic strain which harbors wild type Wars 2 allele (Fig. 2A). There was a general increase in mitochondrial proteosynthesis in SHR-2 congenic strain, as would be expected for moderate aminoacyltRNA synthetase defect in SHR that affects mitochondrial proteosynthesis in general. It reached statistical significance for several mtDNA-encoded subunits of respiratory chain complexes (Nd4, Cyt b, $\mathrm{Nd} 1$ and Nd2). Presumably, this reflects number of tryptophan residues in individual protein subunits, as significant differences were observed in proteins with the highest number of tryptophans (13 times in $\mathrm{Nd} 4$, 10 times in $\mathrm{Cyt}$ b). An analogous downregulation of mitochondrial protein synthesis was observed in SHR cardiomyocytes (data not shown). In addition, lower rate of mitochondrial protein synthesis apparently affected respiratory chain function as isolated mitochondria from SHR versus SHR-2 congenic rats showed significantly reduced ADP-stimulated respiration with NADH-dependent substrates (glutamate and malate), as well as the respective respiratory control index (Fig. 2B).
A

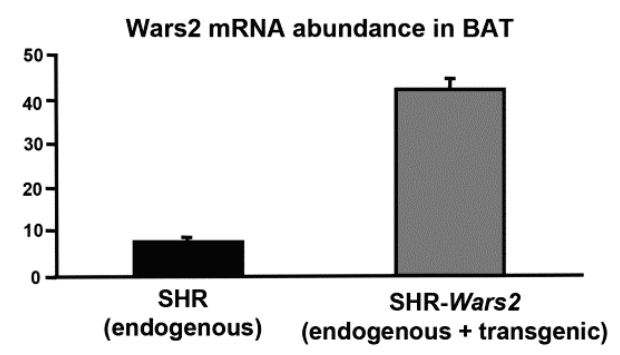

B

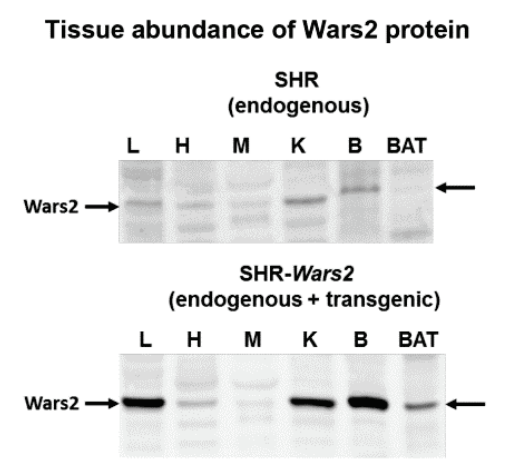

C

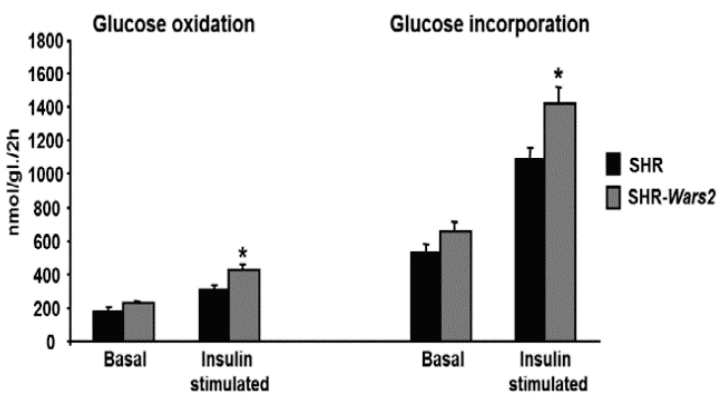

Fig. 1. Expression of Wars2 in BAT isolated from SHR-Wars2 transgenic rats and SHR rats and glucose oxidation and incorporation into BAT lipids. (A) Wars2 mRNA abundance $(n=4$ per strain). (B) Western blot detected WARS2 protein tissue abundance. The methods detect both SHR-specific mutant type and wild type forms of Wars2 ( $n=6$ per strain). (C) SHR-Wars2 transgenic rats with wild type Wars2 exhibited increased glucose oxidation and incorporation into BAT lipids when compared to SHR controls ( $n=8$ per strain). $\mathrm{L}-$ liver, $\mathrm{H}-$ heart, $M-$ muscle, $\mathrm{K}$ - kidney, $\mathrm{B}-$ brain, BAT - brown adipose tissue.

Effects of Wars2 gene variants on capillary density in BAT Since mutant Wars 2 was originally identified as a genetic determinant of reduced cardiac angiogenesis in the SHR (Wang et al. 2016), we tested whether decreased glucose oxidation and glucose incorporation into BAT lipids is due to reduced angiogenesis. No significant differences in capillary density were observed in BAT isolated from SHR and SHR-2 congenic rats (Fig. 3). These results suggest that mutant Wars2 does not affect BAT glucose metabolism through reduced angiogenesis and decreased capillary density. 
A Labelling of mtDNA-encoded mitochondrial proteins

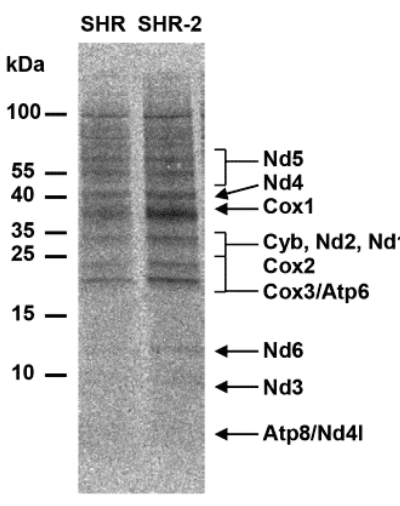

${ }^{* 35}$ S-Met signal

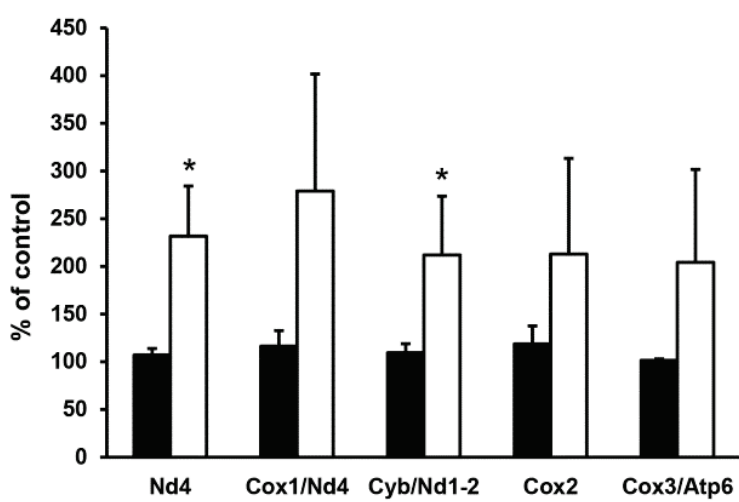

B

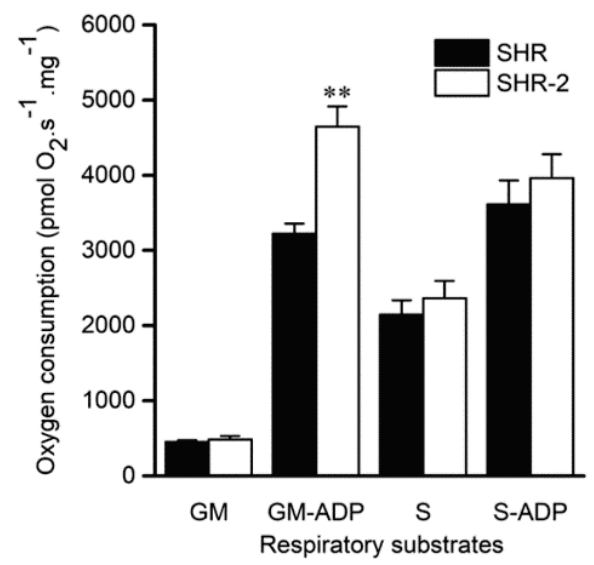

A
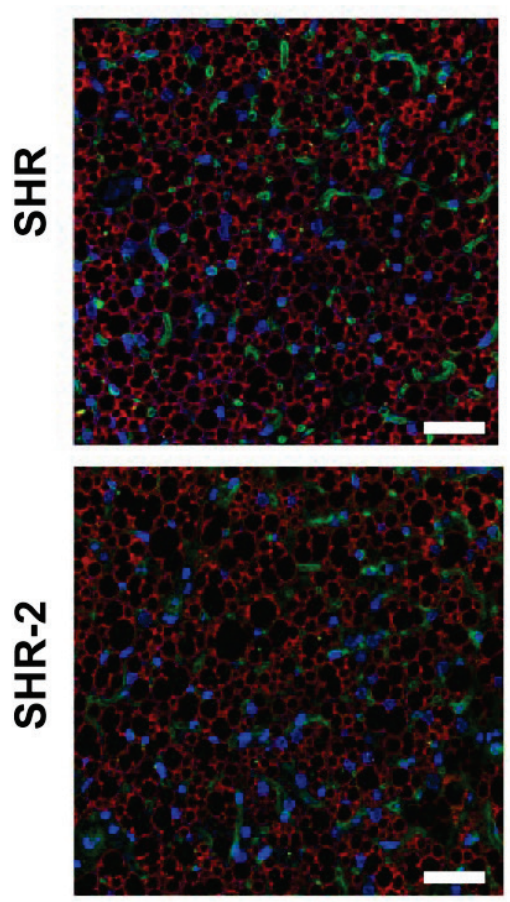

B
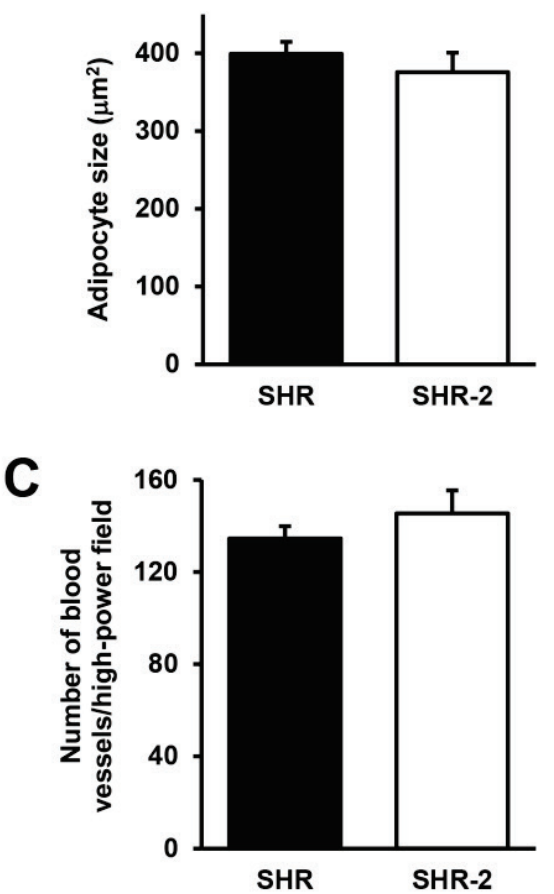

Fig. 2. Effects of Wars2 gene variant on mitochondrial proteosynthesis and respiration. (A) Synthesis of mtDNAencoded proteins in fibroblasts isolated from SHR with mutant Wars2 gene and SHR-2 congenic rats with wild type Wars 2 gene. ${ }^{* 35} \mathrm{~S}$ methionine incorporation in the presence of emetine, an inhibitor of translation of nuclear DNA encoded proteins on cytosolic ribosomes. Specific labelling of mtDNA-encoded proteins (ND1, ND2, ND4 - subunits of respiratory chain complex I; COX2, COX3 subunits of complex IV, ATP6 subunit of ATP synthase) was normalized to mitochondrial porin content and expressed in \% of SHR mean value ( $n=5$ per strain). (B) Mitochondrial respiration using glutamate + malate (GM) or succinate (S) as a substrate was performed in the presence and absence of ADP and is expressed per $\mathrm{mg}$ protein. Respiratory control index (RCI) for the substrate used was calculated as a ratio between respiration in the presence and absence of ADP ( $n=5$ per strain).
Fig. 3. Immunohistochemical characterization of brown adipose tissue of SHR and SHR-2 congenic rats. (A) Immunofluorescence analysis using isolectin IB4 (green; Alexa Fluor 568-conjugate) and antibody to perilipin A (red; Alexa Fluor 633 anti-goat IgG); nuclei counterstained by DAPI (blue). Scale bar, $20 \mu \mathrm{m}$. (B) The size of brown adipocytes was assessed using antibody to sodiumpotassium ATPase; 800 objects per sample were analyzed $(n=6)$. (C) Vascularization was assessed as isolectin-detected capillaries per high-power field; 6 microphotographs per sample were analyzed $(n=6)$. 
Table 1. Correlations of BAT traits with metabolic parameters in 30 RI strains.

\begin{tabular}{lcc}
\hline Phenotype & r value & P value \\
\hline Glucose oxidation in BAT & -0.60 & 0.0005 \\
Body weight & 0.57 & 0.008 \\
Adrenaline-stimulated lipolysis in epididymal fat (glycerol) & 0.47 & 0.02 \\
Adrenaline-stimulated lipolysis in epididymal fat (NEFA) & -0.40 & 0.04 \\
Insulin-stimulated glucose uptake in isolated WAT adipocytes & 0.44 \\
Glucose incorporation into BAT lipids & 0.39 & 0.02 \\
Insulin-stimulated glycogenesis in diaphragm & 0.04 \\
Basal glycogenesis in diaphragm & \\
\hline
\end{tabular}

Correlation analyses of BAT phenotypes with metabolic traits in $B X H / H X B$ recombinant inbred strains

As can be seen in Table 1, glucose oxidation in BAT correlated negatively with body weight and insulin stimulated glucose uptake in isolated WAT adipocytes but positively with stimulated lipolysis in WAT. Glucose incorporation into BAT lipids correlated positively with glucose incorporation into skeletal muscle glycogen (glycogenesis). Both increased lipolysis in white adipose tissue and enhanced glucose incorporation in skeletal muscle indicate the amelioration of insulin resistance.

\section{Discussion}

In the current studies, we performed in vivo transgenic rescue experiments to identify two closely linked QTL on chromosome 2 associated with glucose oxidation and glucose incorporation into BAT lipids as a variant of the Wars 2 gene. The SHR-Wars 2 transgenic rats exhibited significantly increased glucose oxidation and glucose incorporation into BAT lipids when compared to nontransgenic SHR. These results are consistent with differences in glucose oxidation and incorporation into BAT lipids observed previously in SHR-2 congenic rats with wild type Wars 2 allele versus SHR (Pravenec et al. 2017). Originally, the SHR Wars 2 mutant allele was identified as a genetic determinant of reduced cardiac angiogenesis when it was demonstrated that SHR-2 congenic rats had significantly higher capillary number when compared to SHR rats (Wang et al. 2016). Contrary to the heart tissue, the SHR Wars2 mutant variant had no significant effect on BAT capillary number in the SHR-2 congenic versus SHR rats but was associated with a general reduction in the synthesis of mitochondrial proteins. Thus it is possible that reduced proteosynthesis in BAT mitochondria and associated reduced mitochondrial function (decreased respiration) is responsible for lower glucose oxidation and incorporation into BAT lipids.

Transgenic rescue experiments showed that wild type Wars 2 allele was associated with lower body weight to which contributed significantly reduced weight of visceral fat. Congruently, meta-analysis of 32 genomewide association studies (GWAS) in humans revealed a significant association of single nucleotide polymorphisms (SNPs) within the TBX15-WARS2 haplotype with waist-to-hip ratio (Heid et al. 2010, Yoneyama et al. 2017). These associations were reproduced by Liu et al. (2014) and TBX15-WARS2 as a genetic determinant of regional fat distribution was mapped within a narrow region of $\pm 250 \mathrm{~kb}$ (Liu et al. 2014). Unfortunately, no definitive functional SNPs were identified within this locus (Yoneyama et al. 2017). Although reduced visceral fat in SHR-Wars2 rats is causally linked to the transgene expression, it is conceivable that in humans, the TBX15 gene variant might be responsible for the observed association with fat distribution. For instance, it has been demonstrated that TBX15 is differentially expressed in subcutaneous and visceral fat depos in humans and mice (Gesta et al. 2011); but this is also true for the WARS2 gene (Heid et al. 2010). Altogether these findings strongly suggest that TBX15-WARS2 haplotype in humans and Wars 2 gene in the SHR affect the amount of visceral fat.

Glucose oxidation in BAT associated with the Wars 2 gene correlated inversely with glucose incorporation into WAT adipocytes in RI strains (www.genenetwork.org). This result suggests that glucose was preferentially used for oxidation in BAT and not for lipogenesis and fat accumulation. Inverse correlation of glucose oxidation with body weight might reflect reduced adiposity due to a more effective 
mitochondrial function in BAT. Glucose incorporation into BAT lipids in RI strains (www.genenetwork.org) was correlated with increased lipolysis of WAT and higher sensitivity of skeletal muscles to insulin action, i.e. these BAT traits were associated with amelioration of insulin resistance. These results suggest that Wars 2 gene, by affecting BAT function, plays an important role in glucose and lipid metabolism in the SHR model. Interestingly, expression of the Wars2 gene in white adipose tissue in the mouse $\mathrm{BXD}$ recombinant inbred strains (derived from $\mathrm{C} 57 \mathrm{BL} / 6$ and $\mathrm{DBA} / 2$ progenitors) is inversely correlated with obesity trait (body weight gain 17 to 18 days after feeding a high-fat diet, $\mathrm{r}=-0.87, \mathrm{P}=0.00006$ ) which is in agreement with our results that reduced Wars 2 expression might predispose to obesity (Brockmann et al., unpublished results, www.genenetwork.org). Thus variants in Wars2 gene are linked to obesity traits both in rodent models and in humans.

In summary, results of the current study provide the evidence for important role of Wars2 gene in regulating BAT function and consequentially lipid and glucose metabolism in the SHR when SHR mutant variant is associated with reduced mtDNA proteosynthesis, lower mitochondrial function and predisposition to increased visceral fat accumulation.

\section{Conflict of Interest}

There is no conflict of interest.

\section{Acknowledgements}

This work was supported by the Czech Science Foundation (grant number 13-04420S) to MP.

\section{References}

BARTELT A, BRUNS OT, REIMER R, HOHENBERG H, ITTRICH H, PELDSCHUS K, KAUL MG, TROMSDORF UI, WELLER H, WAURISCH C, EYCHMÜLLER A, GORDTS PL, RINNINGER F, BRUEGELMANN K, FREUND B, NIELSEN P, MERKEL M, HEEREN J: Brown adipose tissue activity controls triglyceride clearance. Nat Med 17: 200-205, 2011.

BRADFORD MM: A rapid and sensitive method for the quantification of microgram quantities of protein using the principle of protein dye binding. Anal Biochem 72: 248-254, 1976.

GESTA S, BEZY O, MORI MA, MACOTELA Y, LEE KY, KAHN CR: Mesodermal developmental gene Tbx15 impairs adipocyte differentiation and mitochondrial respiration. Proc Natl Acad Sci U S A 108: 2771-2776, 2011.

HEID IM, JACKSON AU, RANDALL JC, WINKLER TW, QI L, STEINTHORSDOTTIR V, THORLEIFSSON G, ZILLIKENS MC, SPELIOTES EK, MÄGI R, WORKALEMAHU T, WHITE CC, BOUATIA-NAJI N, HARRIS TB, BERNDT SI, INGELSSON E, WILLER CJ, WEEDON MN, LUAN J, VEDANTAM S, ET AL.: Meta-analysis identifies 13 new loci associated with waist-hip ratio and reveals sexual dimorphism in the genetic basis of fat distribution. Nat Genet 42: 949-960, 2010.

IVICS Z, MÁTÉS L, YAU TY, LANDA V, ZÍDEK V, BASHIR S, HOFFMANN OI, HIRIPI L, GARRELS W, KUES WA, BÖSZE Z, GEURTS A, PRAVENEC M, RÜLICKE T, IZSVÁK Z: Germline transgenesis in rodents by pronuclear microinjection of Sleeping Beauty transposons. Nat Protoc 9: 773-793, 2014.

LIU CT, MONDA KL, TAYLOR KC, LANGE L, DEMERATH EW, PALMAS W, WOJCZYNSKI MK, ELLIS JC, VITOLINS MZ, LIU S, PAPANICOLAOU GJ, IRVIN MR, XUE L, GRIFFIN PJ, NALLS MA, ADEYEMO A, LIU J, LI G, RUIZ-NARVAEZ EA, CHEN WM, ET AL.: Genome-wide association of body fat distribution in African ancestry populations suggests new loci. PLoS Genet 9: e1003681, 2013.

LIU CT, BUCHKOVICH ML, WINKLER TW, HEID IM; AFRICAN ANCESTRY ANTHROPOMETRY GENETICS CONSORTIUM; GIANT CONSORTIUM, BORECKI IB, FOX CS, MOHLKE KL, NORTH KE, ADRIENNE CUPPLES L: Multi-ethnic fine-mapping of 14 central adiposity loci. Hum Mol Genet 23: 4738-4744, 2014.

MULLIGAN MK, MOZHUI K, PRINS P, WILLIAMS RW: GeneNetwork: a toolbox for systems genetics. Methods Mol Biol 1488: 75-120, 2017. 
PECINA P, ČAPKOVÁ M, CHOWDHURY SK, DRAHOTA Z, DUBOT A, VOJTÍŠKOVÁ A, HANSÍKOVÁ H, HOUŠŤKOVÁ H, ZEMAN J, GODINOT C, HOUŠTĚK J: Functional alteration of cytochrome c oxidase by SURF1 mutations in Leigh syndrome. Biochim Biophys Acta 1639: 53-63, 2003.

PECINOVÁ A, DRAHOTA Z, NU゚SKOVÁ H, PECINA P, HOUŠTĚK J: Evaluation of basic mitochondrial functions using rat tissue homogenates. Mitochondrion 11: 722-728, 2011.

PFAFFL MW, HORGAN GW, DEMPFLE L: Relative expression software tool (REST) for group-wise comparison and statistical analysis of relative expression results in real-time PCR. Nucleic Acids Res 30: e36, 2002.

PRAVENEC M, ZÍDEK V, MUSILOVÁ A, VORLÍČEK J, KŘEN V, ST LEZIN E, KURTZ TW: Genetic isolation of a blood pressure quantitative trait locus on chromosome 2 in the spontaneously hypertensive rat. $J$ Hypertens 19: 1061-1064, 2001.

PRAVENEC M, SABA LM, ZÍDEK V, LANDA V, MLEJNEK P, ŠILHAVÝ J, ŠIMÁKOVÁ M, STRNAD H, TRNOVSKÁ J, ŠKOP V, HÜTTL M, MARKOVÁ I, OLIYARNYK O, MALÍNSKÁ H, KAZDOVÁ L, SMITH H, TABAKOFF B: Systems analysis of brown adipose tissue function in recombinant inbred rats. Physiol Genomics in press 2017, doi: 10.1152/physiolgenomics.00091.2017

SELUANOV A, VAIDYA A, GORBUNOVA V: Establishing primary adult fibroblast cultures from rodents. $J$ Vis Exp 44: 2033, 2010.

VIJGEN GH, BOUVY ND, TEULE GJ, BRANS B, SCHRAUWEN P, VAN MARKEN LICHTENBELT WD: Brown adipose tissue in morbidly obese subjects. PLoS One 6: e17247, 2011.

VIRTANEN KA: The rediscovery of BAT in adult humans using imaging. Best Pract Res Clin Endocrinol Metab 30: 471-477, 2016.

WANG M, SIPS P, KHIN E, ROTIVAL M, SUN X, AHMED R, WIDJAJA AA, SCHAFER S, YUSOFF P, CHOKSI PK, KO NS, SINGH MK, EPSTEIN D, GUAN Y, HOUŠTĚK J, MRÁČEK T, NƯSKOVÁ H, MIKELL B, TAN J, PESCE F, KOLÁŘ F, BOTTOLO L, MANCINI M, HÜBNER N, PRAVENEC M, PETRETTO E, MACRAE C, COOK SA: Wars2 is a determinant of angiogenesis. Nat Commun 7: 12061, 2016.

YONEYAMA S, YAO J, GUO X, FERNANDEZ-RHODES L, LIM U, BOSTON J, BUZKOVÁ P, CARLSON CS, CHENG I, COCHRAN B, COOPER R, EHRET G, FORNAGE M, GONG J, GROSS M, GU CC, HAESSLER J, HAIMAN CA, HENDERSON B, HINDORFF LA, ET AL.: Generalization and fine mapping of European ancestry-based central adiposity variants in African ancestry populations. Int J Obes (Lond) $\mathbf{4 1}$ : 324-331, 2017. 